\title{
BIOSINTESA FOLAT OLEH BAKTERI ASAM LAKTAT
}

\author{
Siti Nur Purwandhani ${ }^{1}$
}

\begin{abstract}
Folate, an important B-group vitamin, participates in many metabolic pathways such as DNA and RNA biosynthesis and amino acid inter-conversions. Mammalian cells cannot synthesize folate; therefore, an exogenous supply of this vitamin is necessary to prevent nutritional deficiency. Folic acid is a composite molecule, being made up of three parts: a pteridine ring system (6-methylpterin), para-aminobenzoic acid, and glutamic acid. The folate biosynthesis pathway in micro-organisms can be divided in several parts. The pteridine proportion of folate is made from GTP, that is synthesized in the purine biosynthesis pathway. p-Aminobenzoic acid originates from chorismate and can be synthesized via the same biosynthesis pathways required for the aromatic amino acids, involving glycolysis, pentose phosphate pathway and shikimate pathway. The third component of a folate molecule is glutamate, that is normally taken up from the medium. This review will focus on biosynthesis and folate production by lactic acid bacteria and the folate level production in fermented product.
\end{abstract}

Keywords: folate, vitamin, lactic acid bacteria, fermented dairy product

\begin{abstract}
ABSTRAK
Folat, merupakan kelompok vitamin B yang berpartisipasi dalam berbagai jalur metabolisme seperti biosintesis DNA, RNA, dan asam amino. Sel mamalia tidak dapat mensintesis folat; oleh karena itu diperlukan asupan vitamin ini untuk mencegah kekurangan nutrisi. Asam folat adalah molekul campuran, yang terdiri dari tiga bagian: cincin pteridin (6methylpterin), asam para-aminobenzoat, dan asam glutamat. Jalur biosintesis folat dalam mikroorganisme dapat dibagi dalam beberapa bagian. Pteridin pada folat terbentuk dari GTP, yang disintesis dari jalur biosintesis purin. Asam paraaminobenzoat berasal dari chorismate dan dapat disintesis melalui jalur biosintesis yang sama sebagaimana asam amino aromatik, yang melibatkan glikolisis, lintasan pentosa fosfat dan jalur shikimate. Komponen ketiga dari molekul folat adalah glutamat, yang biasanya diambil dari media. Tulisan ini fokus pada biosintesis dan produksi folat oleh bakteri asam laktat serta jumlah folat dalam produk fermentasi.
\end{abstract}

Kata kunci: folat; vitamin; bakteri asam laktat; produk fermentasi susu

\section{Pendahuluan}

Vitamin B 9 atau folat adalah nutrisi penting yang tidak bisa diproduksi oleh mamalia, akan tetapi diproduksi oleh tanaman dan mikroorganisme (Burgess et al., 2009). Folat berfungsi dalam metabolisme asam amino dan nukleotida di dalam sel, seperti sintesa DNA dan RNA, biosintesis gugus metil, vitamin, dan beberapa asam amino (Scott, 1999).

Folat menjadi perhatian karena perannya yang mampu mencegah resiko cacat lahir pada bayi, misalnya cacat pembuluh syaraf (neural tube defect/NTD) (Daly et al., 1995). Menurut World Health Organization (WHO), defisiensi folat merupakan masalah kesehatan masyarakat. Rendahnya status gizi folat menyebabkan resiko terkena osteoporosis (Baines et al., 2007), penyakit jantung koroner (Iyer dan Tomar, 2009), dementia dan Alzheimer's (Luchsinger et al., 2007), anemia (Fishman et al., 2000) serta meningkatnya resiko kanker (Morrison et al., 1995), juga menurunnya kemampuan mendengar (Durga et al., 2007), dan menurunnya performa kognitif (Mitchell et al., 2004).

Diantara mikroorganisme food-grade, terutama BAL diketahui mampu memproduksi folat dalam jumlah banyak (Hugensmith et al., 2010). Produksi folat yang dihasilkan bakteri asam laktat tergantung pada spesies, strain dan kondisi inkubasinya (Lin \& Young, 2000). Pada fermentasi yogurt, keju dan produk fermentasi yang lain BAL meningkatkan asam folat, niacin, riboflavin, serta vitamin B12 dan B6 (Tannock, 1997; Salminen et al., 1998).

\footnotetext{
${ }^{1}$ Program Studi Teknologi Pangan Fakultas Teknologi Pertanian Universitas Widya Mataram Yogyakarta Email: siti_nurp@yahoo.co.id
} 


\section{Bakteri asam laktat (BAL)}

Bakteri asam laktat adalah kelompok bakteri yang dalam kehidupannya dapat memetabolisme karbohidrat (gula) dan menghasilkan asam laktat sebagai hasil utamanya. BAL homofermentatif adalah BAL yang hanya menghasilkan asam laktat sebagai produknya, dan BAL homofermentatif sering digunakan dalam pengawetan makanan, karena produksi asam laktat dalam jumlah tinggi di dalam makanan dapat menghambat pertumbuhan bakteri lainnya yang menyebabkan kebusukan makanan. Pada kelompok bakteri ini asam piruvat yang terbentuk dari jalur glikolisis (EMP) bertindak sebagai penerima hidrogen, dimana reduksi asam piruvat oleh NADH2 menghasilkan asam laktat (Mayo, 2010).

Bakteri asam laktat (BAL) terdapat dalam bahan makanan baik bahan makanan mentah maupun bahan makanan hasil olahan. Keterlibatan BAL tidak hanya dalam masalah pengawetan makanan tetapi juga mampu menghasilkan senyawa-senyawa yang memiliki kontribusi terhadap sifat sensoris suatu makanan (Daeschel, 1989). BAL telah digunakan secara luas sebagai starter dalam fermentasi makanan karena kemampuannya mengkonversi gula menjadi asam-asam organik sehingga meningkatkan sifatsifat organoleptik dan rheologi produk (van Hylckama dan Hugenholtz, 2007).

Beberapa strain BAL mempunyai kemampuan mensintesis vitamin $\mathrm{B}_{12}$ dan asam folat. Kecepatan biosintesis tergantung dari temperatur dan lama inkubasi serta faktor-faktor lain. Starter BAL untuk produksi keju, aktif mensintesis vitamin $B_{12}$ dan asam folat, sehingga keju yang dihasilkan mengandung vitamin $B$ yang cukup tinggi. Penelitian lain menyatakan bahwa hasil proses fermentasi serealia menggunakan BAL akan meningkatkan thiamin dan riboflavin secara significan (Shahani, 1983).

\section{Asam folat}

Asam folat (Pte Glu, 2-amino-4-hidroksi-6metilen amino pteridin-L-asam glutamat) tersusun dari asam para amino benzoat yang ujungnya terhubung dengan satu ujung cincin pteridin dan ujung lain dengan L-glutamic acid, atau suatu pteridin yang diikat melalui gugus metilen pada posisi C-6 gugus amino benzoil glutamate (LeBlanc et a.l, 2007). Asam folat disebut juga folasin $=$ PGA $=$ pteroyl glutamic acid, dengan rumus kimia sebagai berikut pada Gambar 1a.

Secara alami folat berada dalam keadaan tereduksi, satu karbon menggantikan bentuk pteroylglutamat, berbeda dalam substituent dan jumlah residu glutamil yang menempel pada gugus pteroyl. Fraksi 1-C yang dibawa oleh tetrahidrofolat dapat berupa metil, metilen, metenil, formil dan formimino (Gambar 1b).

Sel mamalia tidak mampu mensintesa asam folat, sehingga harus disuplai dari luar untuk menghindari kekurangan nutrisi. Folat terdapat dalam legum (kedelai dan kacang tanah) sebesar 92 $\mu \mathrm{g} / 100 \mathrm{~g}$; sayuran berdaun hijau (bayam) mengandung folat $128 \mu \mathrm{g} / 100 \mathrm{~g}$, brokoli mengandung folat 65 $\mu \mathrm{g} / 100 \mathrm{~g}$, kubis $53 \mu \mathrm{g} / 100 \mathrm{~g}$; beberapa buah-buahan, seperti pepaya dan mangga mengandung folat 32 $\mu \mathrm{g} / 100 \mathrm{~g}$, jeruk mengandung folat $26 \mu \mathrm{g} / 100 \mathrm{~g}$, pisang $19 \mu \mathrm{g} / 100 \mathrm{~g}$; gandum dan roti mengandung folat 16 $\mu \mathrm{g} / 100 \mathrm{~g}$, serta daging $18 \mu \mathrm{g} / 100 \mathrm{~g}$ (Subar et al., 1989). Sebagai alternatif lain pemenuhan asam folat adalah dengan mengkonsumsi produk fermentasi bakteri asam laktat, misalnya susu fermentasi seperti yogurt dan kefir.
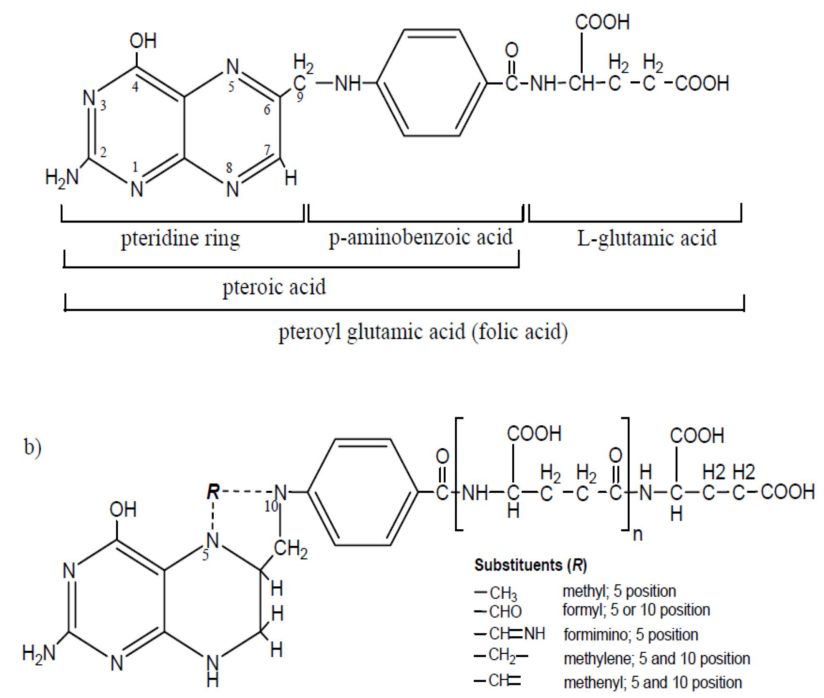

Gambar 1. Struktur asam folat (pte Glu) 1a) dan struktur folat di alam, tereduksi, satu karbon menggantikan polyglutamat 1b) (Sumber : LeBlanc et al., 2007) 
Angka kecukupan gizi folat yang dianjurkan per orang per hari bagi manusia dewasa 200 - $400 \mu \mathrm{g}$ sedangkan untuk wanita hamil memerlukan 600 $\mu \mathrm{g}$ dan ibu yang menyusui memerlukan $500 \mu \mathrm{g}$ per hari (Iyer \& Tomar, 2009). Kebutuhan folat bisa diatasi dengan mengkonsumsi asam folat sintetis atau sayuran hijau; buah-buahan seperti jeruk/Lemon, pisang, melon; kacang-kacangan, daging dan produk makanan yang difortifikasi. Selain itu, sebagai alternatif pemenuhan asam folat adalah dengan mengkonsumsi produk fermentasi bakteri asam laktat (Lin and Young, 2000; Forssen et al., 2000). Lebih jauh LeBlanc et al., (2011) menyatakan bahwa folat yang biasa digunakan untuk fortifikasi adalah asam folat yang merupakan bentuk sintetis dari folat, sedangkan yang secara alami berada di dalam makanan atau yang diproduksi mikroorganisme adalah semua kelompok derivat folat yang tereduksi termasuk 5-methyltetrahidrofolat (5MTHF) dan polylglutamat. Konsumsi folat natural misalnya 5-MTHF lebih efisien dan aman dibanding dengan konsumsi folat dalam bentuk asam folat sebagai suplemen (Lamers et. al., 2006).

Selain itu pemanfaatan mikroorganisme yang memproduksi vitamin dalam fermentasi makanan lebih natural dan ekonomis dibanding vitamin buatan yang diproduksi secara kimia, dan akan dihasilkan makanan dengan jumlah folat dengan konsentrasi cukup yang meniadakan efek samping yang tidak diinginkan (LeBlanc et al., 2011).

\section{Potensi BAL sebagai penghasil folat}

Berdasar penelitian Gangadharan \& Nanpoothiri (2011), Lactococcus Lactis ssp cremoris yang diisolasi dari susu segar mampu menghasilkan folat $17,2 \mu \mathrm{g} / \mathrm{L}$. Streptococcus thermophillus yang diisolasi dari susu fermentasi menghasilkan folat $20-150 \mu \mathrm{g} / \mathrm{kg}$ (Smid et al., 2001 dalam Holasova et al., 2004). Penelitian Sybesma et al., 2003 menyatakan bahwa Lactobacillus helveticus ATCC 10797 yang merupakan strarter pembuatan keju dapat menghasilkan folat $89 \mu \mathrm{g} / \mathrm{L}$, serta Streptococcus thermophillus dari yogurt menghasilkan folat 29$202 \mu \mathrm{g} / \mathrm{L}$.

Penelitian Wouters et al., 2002 dalam LeBlanc et al., 2011; menyatakan bahwa Lactococcus lactis dan Streptococcus thermophillus mampu meningkatkan kadar folat pada susu fermentasi, dari $20-50 \square \mathrm{g} / \mathrm{L}$ pada susu segar, setelah difermentasi menjadi yogurt kadar folatnya meningkat menjadi $200 \square \mathrm{g} / \mathrm{L}$. Potensi bakteri asam laktat sebagai penghasil folat dapat dilihat pada tabel berikut :

Tabel 1. Potensi bakteri asam laktat sebagai penghasil asam folat

\begin{tabular}{cllll}
\hline \multirow{2}{*}{ No } & Spesies - Strain & Sumber & Media/Level folat & Pustaka \\
\hline 1 & Lactococcus & Susu segar & Susu skim/ & Gangadharan \& \\
& Lactis ssp cremoris & & $17,2(\mu \mathrm{g} / \mathrm{L})$ & Nanpoothiri, 2011 \\
\hline 2 & BAL CM 22 dan CM 28 & Susu segar & Susu skim/ & Gangadaran et al., 2010 \\
& & & $12,5-14,2(\mu \mathrm{g} / \mathrm{L})$ & \\
\hline 3 & Streptococcus & Susu fermentasi & Susu UHT/ & Smid et al., 2001 dalam \\
& thermophillus & & $20-150$ & Holasova et al., 2004 \\
& & & $(\mu \mathrm{g} / \mathrm{kg})$ & \\
\hline 4 & Streptococcus & Yogurt & M17/ & Sybesma et al., 2003 \\
& thermophillus & & $29-202(\mu \mathrm{g} / \mathrm{L})$ & \\
\hline 5 & Lactobacillus helveticus & Swiss-cheese starter & $\mathrm{MRS} /$ & Sybesma et al., 2003 \\
& ATCC 10797 & $89(\mu \mathrm{g} / \mathrm{L})$ & \\
\hline
\end{tabular}

Folat yang terdapat dalam makanan akan hilang $20-75 \%$ selama pengolahan dengan air dan dapat rusak waktu pemanasan. Diantara folat-folat yang tereduksi (tetrahidrofolat/THF) mempunyai stabilitas yang berbeda. Dalam beberapa kasus asam folat mempunyai stabilitas yang lebih tinggi dibanding folat yang tereduksi. Urutan stabilitasnya dari 5-formyl-THF, 5- methyl-THF, 10-formyl-THF, terakhir THF. Stabilitas folat juga tergantung $\mathrm{pH}$; folat yang tereduksi lebih stabil pada $\mathrm{pH}>8$ dan $\mathrm{pH}<2$, dan kurang stabil pada $\mathrm{pH}$ 4-6. Penurunan stabilitas folat karena 
oksidatif meningkat dengan adanya oksigen, cahaya dan panas. Oksidasi menyebabkan pemecahan molekul menjadi bentuk yang tidak aktif, dimana $p$-aminobenzoylglutamate merupakan bentuk utama. Dengan adanya antioksidan dalam jumlah cukup, misalnya asam askorbat dan thiol, akan melindungi folat dari oksidasi. Dengan adanya oksigen, kecepatan reaksi pemecahan folat tergantung pada tipe derivatif folat dan kondisi alami pangan, misalnya $\mathrm{pH}$, komposisi buffer, elemen minor yang bersifat katalitik dan antioksidan (Forsse'n et al., 2000).

Susu fermentasi potensial sebagai sumber folat karena folate binding protein pada susu meningkatkan stabilitas folat dan mendukung bioavailability dari 5methyltetrahidrofolat maupun asam folat (Verwei et al.,, 2003).

\section{Biosintesa folat oleh BAL}

Biosintesis folat (Gambar 2) pada Lactococcus lactis berlangsung melalui konversi GTP (guanosin tripospat) dengan 7 tahap menjadi tetrahidrofolat (THF). Dua reaksi kondensasi berperan dalam jalur biosintesis THF. Reaksi kondensasi pertama adalah antara asam paraaminobenzoat dengan 2-amino-4-hydroxy-6hydroxymethyl-7, 8-dihydropteridine untuk menghasilkan dihydropteroate. Reaksi kondensasi kedua antara glutamat dengan dihydropteroate membentuk dihydrofolate. pABA (paraaminobenzoic acid) disintesa dari jalur pentosa fosfat; pada jalur ini D-erythrose 4-phosphate terkondensasi dengan phosphoenolpyruvate membentuk chorismate. Dari chorismate terbentuk asam amino aromatik (phenil alanin, triptopan dan tyrosin) dan pABA (Wegkamp et al., 2007).

Molekul folat terdiri dari satu cincin pteridin yang berasal dari 6-hydroxymethyl-7,8dihydropterin pyrophosphate (DHPPP) yang berikatan dengan asam para-aminobenzoat (pABA). Jalur de novo biosintesis folat oleh bakteri probiotik, terlihat pada Gambar 2.6., memerlukan dua precursor, DHPPP dan pABA. DHPPP dan pABA bisa diproduksi oleh tanaman dan bakteri dari jalur pentosa fosfat (Rossi et al., 2011).
Erythrose

4-phosphate

dan phosphoenolpyruvate melalui jalur shikimate akhirnya terbentuk chorismate, yang merupakan cabang menuju biosintesis asam amino aromatik dan pABA. Chorismate diubah oleh enzim aminodeoxychorismate synthase (EC 2.6.1.85) menjadi 4-amino-4-deoxychorismate. Kemudian, pyruvate dipecah oleh 4-amino-4deoxychorismate lyase (EC 4.1.3.38) untuk membentuk pABA, yang merupakan prekursor terjadinya biosintesa folat. Biosintesa DHPPP terjadi melalui perubahan guanosin trifosfat (GTP) dengan 4 (empat) tahap yang berurutan.

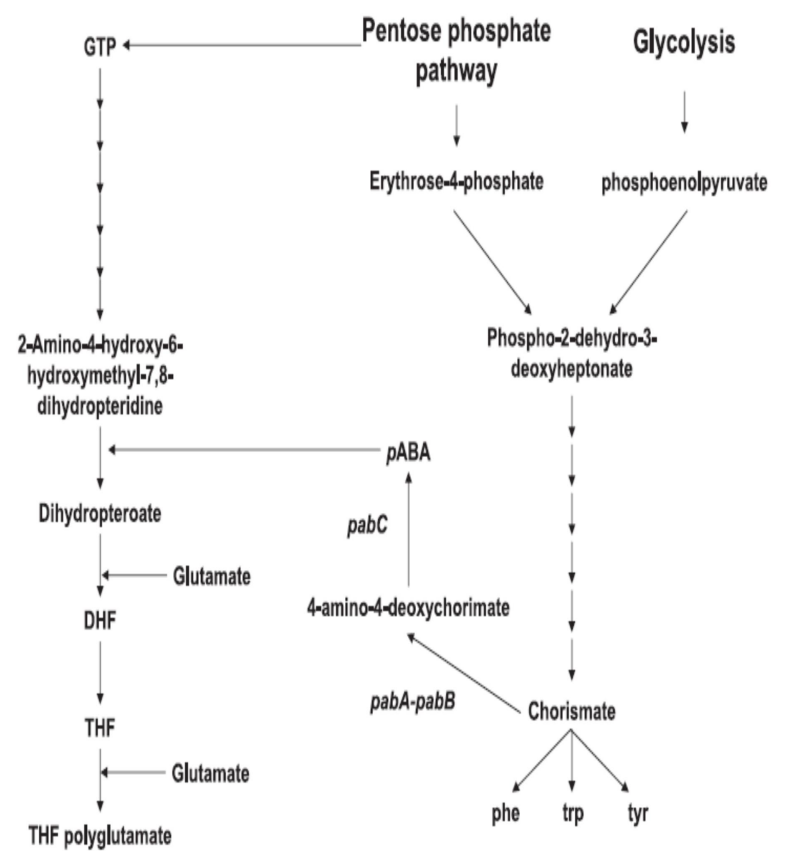

Gambar 2. Jalur biosintesis pABA dan folat pada $L$. lactis , menunjukkan konversi GTP menjadi THF, jalur biosintesis pABA dari chorismate dan perubahan $p \mathrm{ABA}$ menjadi THF. Sumber : Wegkamp et al., 2007.

Tahap yang pertama dikatalisa oleh GTP cyclohydrolase I (EC 3.5.4.16) dan melibatkan perubahan GTP melalui Amadori rearrangement (pengaturan Amadori), untuk membentuk struktur cincin pterin. Diikuti defosforilasi, molekul pterin berubah menjadi aldolase dan reaksi pyrophosphokinase, yang mengaktifkan pyrophosphorylated DHPPP synthase (EC 2.5.1.15) menghasilkan 7,8-dihydropteroate (DHP). Oleh dihydrofolate synthase (EC 6.3.2.12) DHP diubah menjadi dihydrofolat (DHF). Kemudian direduksi oleh DHF reduktase (EC 1.5.1.3) menjadi kofaktor 
tetrahidrofolat (THF) dan dengan penambahan glutamat dalam jumlah banyak oleh folylpolyglutamate synthase (EC 6.3.2.17) untuk menghasilkan THF-polyglutamate. Biosintesa folat berlanjut dengan terbentuknya ikatan C-N yang

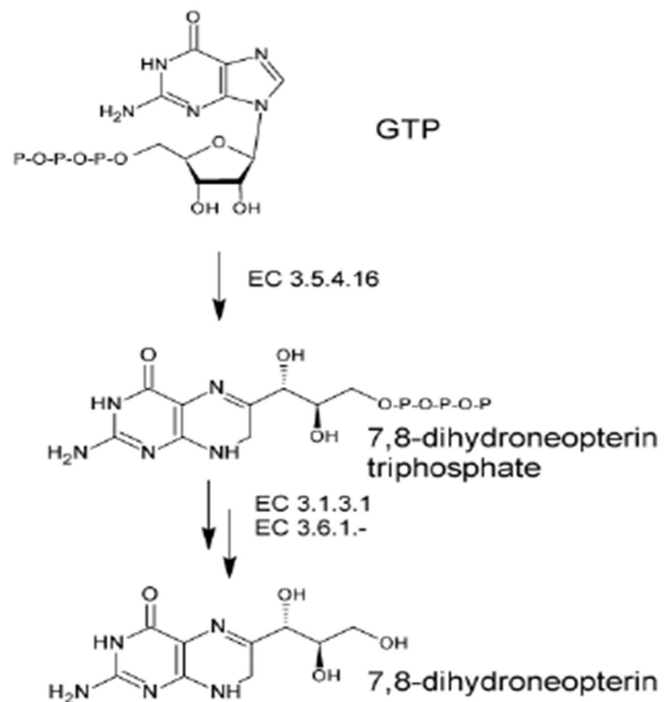

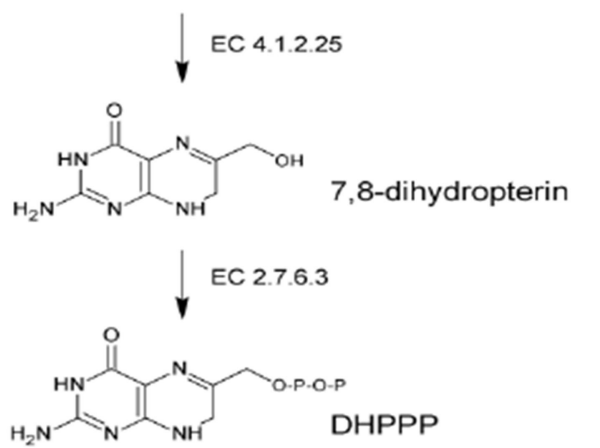

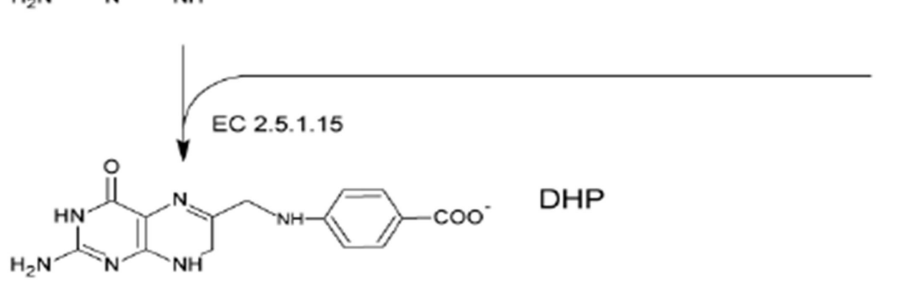

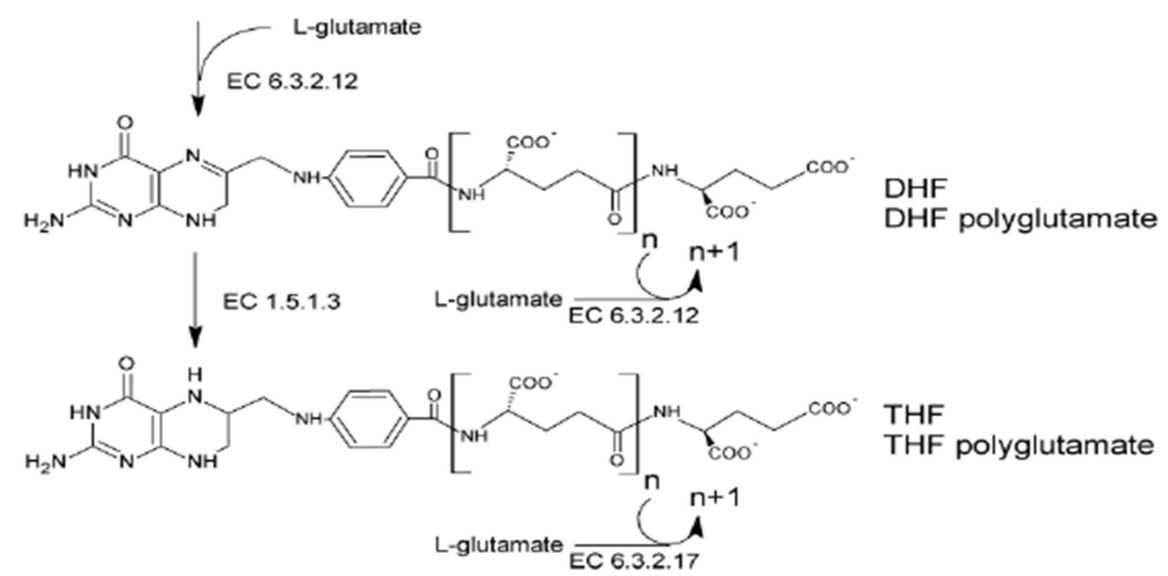

Gambar 3. Jalur de novo biosintesis folat oleh bakteri probiotik (Rossi et al., 2011) dihydropteorat.
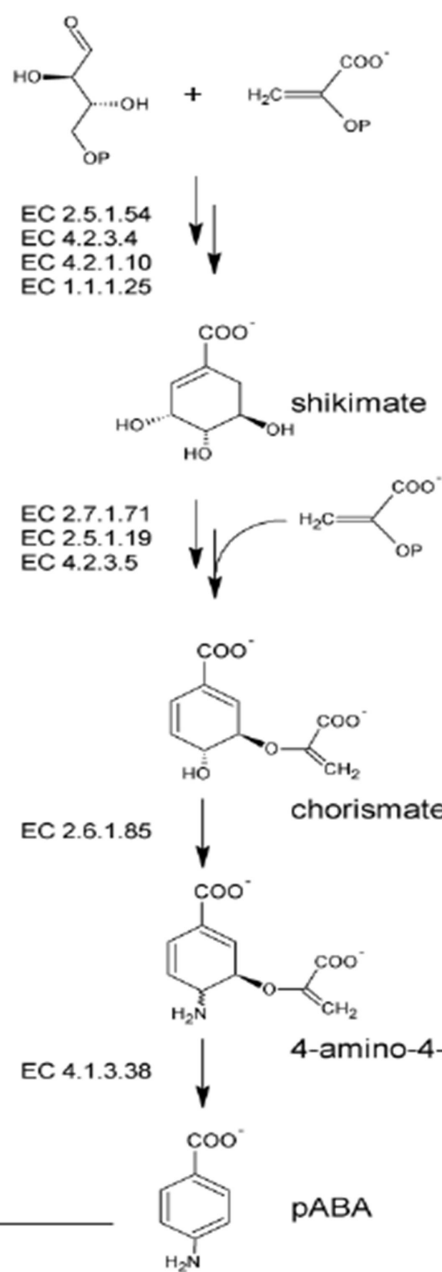

DHF

terbentuk dari bergabungnya DHPPP dengan pABA. Reaksi kondensasi ini dikatalisa oleh

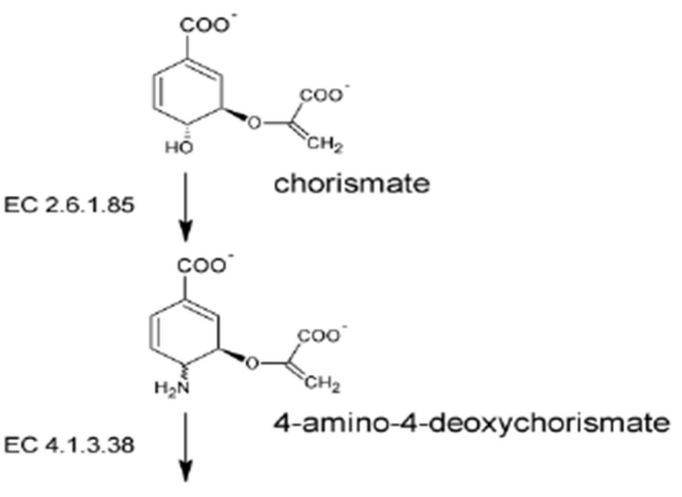




\section{Peningkatan kadar folat oleh BAL pada susu fermentasi}

Bakteri asam laktat penghasil folat dapat meningkatkan kadar folat pada susu fermentasi. Menurut LeBlanc et al., 2011; BAL yang digunakan untuk industri misalnya $L$. lactis dan Streptococcus thermophilus mempunyai kemampuan untuk memproduksi folat, sehingga beberapa produk susu fermentasi, termasuk yogurt, mengandung folat yang lebih tinggi (200 $\mu \mathrm{g} / \mathrm{L})$ dibanding susu segar $(20-50 \mu \mathrm{g} / \mathrm{L})$. Demikian pula penelitian Sanna et al., 2005, bahwa susu kambing segar yang tidak terdeteksi mengandung folat, setelah difermentasi menggunakan Streptococcus thermophilus kandungan folatnya menjadi $24-59 \mu \mathrm{g} / \mathrm{kg}$, dengan Lactobacillus delbrueckii subsp. Bulgaricus menjadi $27-32 \mu \mathrm{g} / \mathrm{kg}$, dengan $L b$. delbrueckii subsp. lactis menjadi $63 \mu \mathrm{g} / \mathrm{kg}$ dan dengan $\mathrm{Lb}$. helveticus $52 \mu \mathrm{g} / \mathrm{kg}$.

Susu segar mengandung folat $50 \mu \mathrm{g} / \mathrm{kg}$. Setelah difermentasi menggunakan BAL, yogurt yang dihasilkan mengandung folat $70-120 \mu \mathrm{g} / \mathrm{kg}$ (Forsse'n et al., 2000). Penelitian lain, oleh Lin \& Young (2000), menyatakan sebelum fermentasi, folat dalam medium susu tanpa lemak $23 \mu \mathrm{g} / \mathrm{L}$, setelah fermentasi 6 jam menggunakan St. thermophillus MC jumlah folat menjadi 59,6 $\mu \mathrm{g} / \mathrm{L}$.

\section{Penutup}

Folat adalah nutrisi penting yang berfungsi dalam sintesa DNA, RNA dan beberapa asam amino. Folat bisa dihasilkan oleh beberapa bakteri asam laktat, misalnya Streptococcus thermophillus dan Lactobacillus plantarum. Biosintesis folat di dalam sel bakteri asam laktat terjadi dari 3 komponen dasar yaitu GTP, paraamino benzoat dan asam glutamat. Folat yang bisa dihasilkan bakteri asam laktat selama fermentasi susu berkisar antara 17,2-202 mg/L

\section{Daftar pustaka}

Baines, M., Kredan, M.B., Usher, J., Davison, A., Higgins, G., Taylor, W., West, C., Fraser, W.D., dan Ranganath, L.R. (2007). The association of homocysteine and its determinants MTHFR genotype, folate, vitamin B12 and vitamin B6 with bone mineral density in postmenopausal British women. Bone 40: 730-736.

Burgess, C. M., Smid, E. J., dan van Sinderen, D. (2009). Bacterial Vitamin B2, B11 and B12 overproduction : An overview. International Journal of Food Microbiology. 133 : 1-7.

Daly, L.E, Kirke, P. N., Molloy, A., Weir, D. G., dan Scott, J. M. (1995). Folate levels and neural tube defects. Journal American Medical Association 247: 1698-702.

Durga, J., Verhoef, P., Anteunis, L. J. C., Schouten, E. dan Kok, F. J. (2007). Effects of folic acid supplementation on hearing in older adults. Annals of Internal Medicine 146: 1-9.

Daeschel, M.A. (1989). Antimicrobial substance of lactic acid bacteria. Journal of Biotechnology. 9(33): 5383-5391.

Durga, J., Verhoef, P.V, Anteunis, L. J. C., Schouten, E., dan Kok, F. J. (2007). Effects of folic acid supplementation on hearing in older adults. Annals of Internal Medicine 146:1-9.

Fishman, S. M., Christian, P., and West Jr., K. P. (2000). The Role of Vitamins in the Prevention and Control of Anaemia. Health Nutrition 3(2): 125 - 150 .

Forsse'n, K. M., Ja"gerstad, M. I., Wigertz, K., dan Wittho"ft., C. M. (2000). Folates and Dairy Products: A Critical Update. Journal of the American College of Nutrition 19(2): 100S-110S.

Gangadharan, D., Nampoothiri, K. M. (2011). Folate production using Lactococcus lactis ssp cremoris with Implications for Fortification of Skim Milk and Fruit Juices. LWT - Food Science and Technol. 44: 1859 -1864 . 
Gangadharan, D., Sivaramakrishnan, S., Pandey, A., and Nampoothiri, K. M. (2010). Folate-producing lactic acid bacteria from cow's milk with probiotic characteristics. International Journal Of Dairy Technology 63 (3): 339-348.

Holasová, M., Fiedlerová, V., Roubal, P., and Pechačová, M. (2004). Biosynthesis of Folates by Lactic Acid Bacteria and Propionibacteria in Fermented Milk. Czech Journal Food Science Vol. 22, No. 5: 175181.

Hugenholtz, J.. (2008). The Lactic Acid Bacterium as a Cell Factory for Food Ingredient Production. International Dairy Journal 18: 466-475.

Hugenschmidt, S., Schwenninger, S. M., Gnehm, N., dan Lacroix, C. (2010). Screening of natural Biodiversity of Lactic and Propionic Acid Bacteria for Folate and Vitamin B12 Production in Supplemented Whey Permeate. International Dairy Journal. 20 : $852-857$.

Iyer, R. dan Tomar, S.K. (2009). Folate: A Functional Food Constituent. Journal of Food Science. 74: R114 - R122

Lamers,. Y, Prinz-Langenohl, R., Bra“mswig, S., dan Pietrzik, K. (2006). Red blood cell folate concentrations increase more after supplementation with [6S]-5methyltetrahydrofolate than with folic acid in women of childbearing age. American Journal Clinical Nutrition 84: 156-61.

Lin, M. Y. dan Young, C.M. (2000). Folate Level in Culture of Lactic Acid Bacteria. International Dairy Journal 10: 409 413.

LeBlanc, J.G., Savoy de Giori, G., Smid, E. J., Hugenholtz, J., dan Sesma, F. (2007). Folate production by lactic acid bacteria and other food-grade Microorganisms. Communicating Current Research and
Educational Topics and Trends in Applied Microbiology. A. Méndez-Vilas: 329 -339

LeBlanc, J.G., Laiño, J.E., Juarez del Valle, M., Vannini, V., van Sinderen, D., Taranto, M.P., Font de Valdez, G., Savoy de Giori, G., dan Sesma, F. (2011). B-Group vitamin production by lactic acid bacteria - current knowledge and potential applications. Journal of Applied Microbiology 111: 1297- 1309 .

Luchsinger, J. A., Tang, M. X., Miller, J., Green, R., dan Mayeux Arch, R. (2007). Relation of Higher Folate Intake to Lower Risk of Alzheimer Disease in the Elderly. American Medical Association 64: 86 -92

Mayo, B., Aleksandrzak-Piekarczyk , T., Fernández , M., Kowalczyk , M., ÁlvarezMartin, P., dan Bardowski, J. (2010). Updates in the metabolism of lactic acid bacteria. Dalam: Mozzi, F., Raya, R, R, dan Vignolo, G. M. (ed). Biotechnology of lactic acid bacteria : Novel Application, hal 3-33. John Wiley \& Sons, Inc. Publication. IOWA. USA.

Mitchell, L. E., Adzick, N S., Melchionne, J., Pasquariello, P. S, Sutton, L. N., dan Whitehead, A. S. (2004). Spina Bifida. The Lancet 364: 1885-1895.

Morrison, H. I., Schaubel, D., Desmeules, M., dan Wigle, D. T. 1996. Serum folate and risk of fatal coronary heart disease. Journal of American Medical Association, June 26, $275: 1893-1896$.

Rossi, M., Amaretti, A., dan Raimondi, S. (2011). Folate production by probiotic bacteria. Nutrients 3:118-134.

Salminen, S., von Wright, A., Morelli, L., Marteau, P., Brassart, D., de Vos, W. M., Fonden, R., Saxelin, M., Collins, K., Mogensen, G., Birkeland, S.E., dan Sandholm, T. M. (1998). Demonstration of 
Safety of Probiotics - a Review. International Journal of Food Microbiology 44: 93 - 106.

Sanna, M. G., Mangia, N. P., Garau, G., Murgia, M. A., Massa, T., Franco, A. and Deiana, P. (2005). Selection of folate-producing lactic acid bacteria for improving fermented goat milk. Italian Journal Food Science 2(17) : 143-154.

Scott, J. M. (1999). Folate and vitamin B12. Proceedings of the Nutrition Society 58 : 441-448

Shahani, K.M. (1983). Nutritional Impact of Lactobacillic Fermented Foods. Dalam: Bo Hallgren, M. D. (ed). Nutrition and the Intestinal Flora. Almqvist \& Wiksell International Stockholm/Sweden

Sybesma, W., Starrenburg, M., Tijsseling, L., Hoefnagel, M. H. N., and Hugenholtz, J. (2003). Effects of cultivation conditions on folate production by lactic acid bacteria. Applied And Environmental Microbiology 69 (8): 4542-4548.

Tannock, G. W. (1997). Probiotic Properties of Lactic-acid Bacteria : Plenty of Scope for Fundamental R \& D. Tibtech July. 15: $270-274$

van Hylckama Vlieg, J. E., Hugenholtz, J. (2007). Mining natural diversity of lactic acid bacteria for flavour and health benefits. International Dairy Journal 17 :1290-1297

Verwei, M., Arkbåge, K., Havenaar, R., van den Berg, H., Witthoft, C., and Schaafsma, G. (2003). Folic Acid and 5Methyltetrahydrofolate in Fortified Milk Are Bioaccessible as Determined in a Dynamic In Vitro Gastrointestinal Model. Nutrition Journal 133: 2377-2383.

Wegkamp, A., Oorschot, W. V., De Vos, W. M., and Smid, E. J. (2007). Characterization Of
The Role Of Para-Aminobenzoic Acid Biosynthesis In Folate Production By Lactococcus Lactis. Applied and Environmental Microbiology 73(8): 26732681. 